\title{
The Design of Sports Club of Pencak Silat in Elementary School
}

\author{
Suratmin \\ Faculty of Sports and Health \\ Universitas Pendidikan Ganesha \\ Singaraja, Indonesia \\ suratmin@undiksha.ac.id
}

\author{
Adnyana Putra \\ Faculty of Sports and Health \\ Universitas Pendidikan Ganesha \\ Singaraja, Indonesia \\ adnyanaputra@undiksha.ac.id
}

\author{
I Putu Darmayasa \\ Faculty of Sports and Health \\ Universitas Pendidikan Ganesha \\ Singaraja, Indonesia \\ iputudarmayasa@undiksha.ac.id
}

\begin{abstract}
-the specific objectives of this development research are (1) to design an elementary school sports club, and (2) to manage the establishment of a pencak silat in an elementary school. This research makes use of the research and development design along with procedure and product trial. Data were collected through questionnaire and interviewing of coaches, physical education teachers, and the head of youth and sports education office. The outcome of the research study (1) analyzes the needs of the youth and sports education offices to the concept of pencak silat sports club in elementary school, (2) the design of pencak silat sports club in elementary schools in Bali province, and (3) guides the establishment of the pencak silat sports club.
\end{abstract}

Keywords—sports club, pencaksilat, elementary school, Bali

\section{INTRODUCTION}

Squatting, early-age sports coaching, nurseries, talent scouting, and student coaching are essential for a strong sporting foundation in order to achieve tremendous success in sports. Strategic steps should be taken in developing talents. Similarly, coaches should ensure that they impact adequate sporting knowledge to their students in a systematic manner, until elite athletes are obtained. This is one of the positive impact associated with coaching at an early age. However, research has it that sporting activities in Indonesia is currently experiencing lots of setbacks, thereby, requiring the attention of the government, sports actors, and stakeholders in sports. This is said to be as a result of the nonchalant and unserious attitudes portrayed by athletes, especially the senior athletes. Various sports organizations in Indonesia have beamed that the proper guidance of sports at the basic level is essential for the proper foundation of sports. According to Ria Lumintuarso, there are some weaknesses associated with the current sporting system making it essential for the development and coaching of sports using pencak silat for the proper establishment of sports clubs in elementary schools, in Bali province.. Establishing an elementary school sports club is absolutely necessary, as it would ensure the systematic and proper recognition of sports clubs in Bali province and in Indonesia as a whole. The Pencak Silat School in Bali is quite diverse with numerous associates such as (1) Bakti Negara, (2) Shield of Self, (3) Kerta Wisesa, (4) Satria Muda Indonesia, (5) Loyal Fraternity of Speech, (6) Merpati Putih, (8) PP Suro, and (9) Pagar Nusa. There are still many associations or colleges of Pencak Silat in Bali.
Pencak is a basic martial movement bound by rules. It is used in learning, practicing and in performances. Silat on the other hand, is a perfect martial movement, originated from pure and holy spirituality. It is used for personal safety to prevent oneself from disasters, such as robbers, diseases, witchcraft and other sort of evil (Sudiana and Spyanawati, 2017). Pencak silat is made up of four aspects or four elements: (1) elements of sport, (2) elements of art, (3) martial arts, and (4) spiritual elements.

Sports coaching must be started at an early age. This is because at an early age, children tend to have a higher degree of flexibility. In addition to this, they are physical and mentally fit and are easily motivated to exercise, thereby, allowing them to improve their ability, and make decisions quickly and accurately. Achieving maximum success in sports, requires approximately 10 years of coaching.

One strategy adopted by coaches is the involvement of sports clubs. Sports clubs are at the forefront of sports coaching including the sport of pencak silat. This club is expected to produce talented athletes (Sri Sudono Sumarto, 2000).

The existence of sports clubs in Indonesia is of great importance, especially among students as it is the spearhead of sports coaching. As a result of this, coaching sports clubs needs to find a way to create a club where strong sports coaching foundations can be realized. Some factors to consider in a sports club are talent scouters, professional trainers, proper training methods, regular competition, athlete welfare, training facilities and infrastructure, and periodic evaluations.

The design to be developed is the Balinese martial arts club design model which is based on scientific assessment as well as on science and technology. Similarly, the youth and sports education that takes care of a student sports club in Bali province requires a model of a student sports club.

The focus of this research study is to develop and design a martial arts sports club model in Bali province, therefore, the research problem formulation can be described as follows: (1) How to create the design concept of martial arts sport club, (2) How to develop and manage the student of the pencak silat sports club, and (3) Preparation of guidelines for the formation of martial arts clubs for students in Bali province. 


\section{METHOD}

The research method used in carrying out this research is the model development method. This research is a development research aimed at producing a pencak silat sports club for students. The testing design method is used to develop, the procedures undertaken in this development study. This study comprises of (1) developing the product, and (2) testing the effectiveness of the product in order to achieve set objectives.

Preparing the design of the elementary school pencak silat sports club begins with analyzing the needs and elements needed for the development of a pencak silat sports club for elementary school students. The analysis was carried out by trainers and sports experts. Furthermore, reference reviews related to the development of pencak silat sports club design for elementary schools was validated. After the validation test by the experts, the next step taken was to test the product by using the pencak silat sports club design for students.

\section{RESULTS}

Branches organized by districts / municipalities in Bali province adjusted to local budgets. These include martial arts sports clubs for elementary school students which was conducted regionally. However, sports coaching conducted by districts / municipalities through the Office of the Youth and Sports, needs the development and formation of martial arts sports club for elementary school students.

TABLE I. BASIC DESIGN Of PENCAK Silat Sports Club In ElEMENTARY SCHOOL

\begin{tabular}{|c|c|c|}
\hline No & Component & Sports Club in Elementary School \\
\hline 1 & Curriculum & Modification of national curriculum \\
\hline 2 & $\begin{array}{l}\text { Learning } \\
\text { system }\end{array}$ & $\begin{array}{l}\text { Module, E-learning, face to face, and teacher } \\
\text { guidance. }\end{array}$ \\
\hline 3 & Subjects & $\begin{array}{l}\text { Fewer subjects is better (Focus on subjects } \\
\text { on national test) }\end{array}$ \\
\hline 4 & Learning time & More flexible than another school \\
\hline 5 & $\begin{array}{l}\text { Coach } \\
\text { qualification }\end{array}$ & $\begin{array}{l}\text { Minimum requirements is bachelor of sports } \\
\text { (combination of ex-athletes and researcher) }\end{array}$ \\
\hline 6 & Coach origin & National or regional level \\
\hline 7 & $\begin{array}{l}\text { Coaching } \\
\text { system }\end{array}$ & $\begin{array}{l}\text { Physical, basic technique, strategy, and } \\
\text { mental coaching combined with discipline, } \\
\text { character. }\end{array}$ \\
\hline 8 & $\begin{array}{l}\text { Athletes } \\
\text { selection }\end{array}$ & $\begin{array}{l}\text { Students with sports talents obtained through } \\
\text { natural and science-based talent scouting. }\end{array}$ \\
\hline 9 & Fund & Enough for training requirements \\
\hline 10 & $\begin{array}{l}\text { Selection } \\
\text { system }\end{array}$ & $\begin{array}{l}\text { Twice a year done through sports science } \\
\text { and minimum standard rule }\end{array}$ \\
\hline 11 & $\begin{array}{l}\text { Talent } \\
\text { scouting }\end{array}$ & Need to be supported by sports science. \\
\hline 12 & $\begin{array}{l}\text { Infrastructure } \\
\text { and facility, } \\
\text { and equipment }\end{array}$ & Provided by the government \\
\hline 13 & Try out & National and local level \\
\hline 14 & $\begin{array}{l}\text { Achievement } \\
\text { data base }\end{array}$ & Must be well-managed \\
\hline 15 & $\begin{array}{l}\text { Training } \\
\text { duration }\end{array}$ & 2-3 hours per day \\
\hline 16 & $\begin{array}{l}\text { Promotion and } \\
\text { degradation }\end{array}$ & Twice a year \\
\hline 17 & Competition & Many and routine \\
\hline 18 & $\begin{array}{l}\text { Sports } \\
\text { achievement }\end{array}$ & Minimally local champion \\
\hline 19 & Club's target & $\begin{array}{l}\text { Sports club in elementary school were built } \\
\text { in } 9 \text { districts and cities. }\end{array}$ \\
\hline
\end{tabular}

Based on the results of interviews with the head of the sports field Education Youth and Sports district / city in the province of Bali, it can be seen that the design of martial arts sports clubs on SD students, was not done with the assessment and scientific approach. It has been proven that (1) the new elementary school martial arts sports club will be established, (2) the need for elementary sports clubs in schools, especially the fulfillment of sports facilities (3) the name of the existing elementary school student sports club varies accordingly. (4) The sports branch handled by each regency / city focuses on sports, games, martial arts, and accuracy according to each regions potential, (5) number of elementary school student sports clubs, (6) unavailability of the recruitment system of talented sports students, (7) unfilled training facilities and equipment, and (7) funding sources in coaching the student sports club SD districts / cities in the province of Bali in accordance with their respective regions.

The development and management of sports and martial arts in elementary school, should be handled by competent institutions such as; local government, sports office, local branches of national sports committee, district or city branch manager of sports, sports faculty in higher education institutions, and other supporting institutions.

The organizational chart of elementary school martial arts students can be seen below.

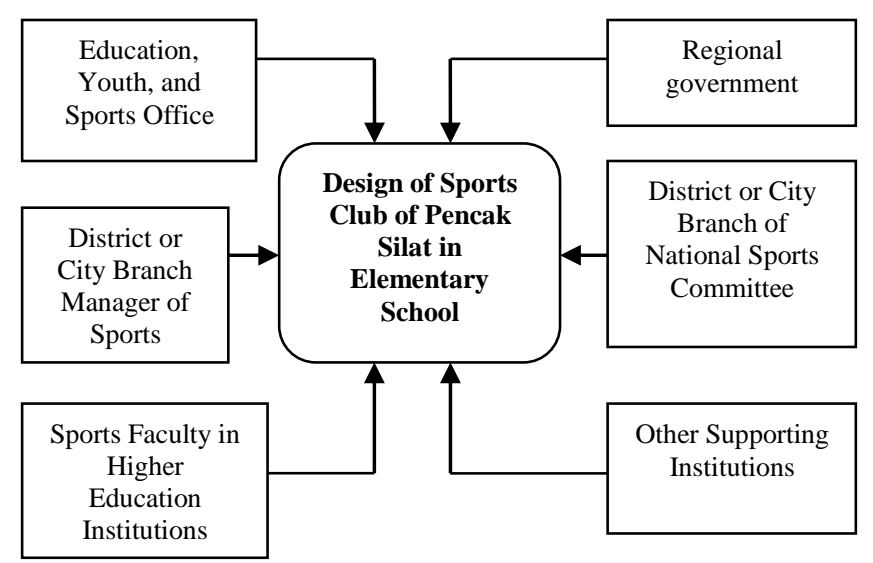

Fig. 1. Organizational chart design of pencak silat sports club in elementary schools

The trainer is the primary sportsman involved in the whole process. He ensures that sports achievement are improved in-line with the design of the elementary school pencak silat sports club. As the leader of increased sporting achievements, professional trainers are expected to run a good training program. Proper test is carried out to determine the trainer's capability. Here are some of the criteria that must be possessed by the trainer in order to design a sports club model for elementary school students: 
TABlE II. CRITERIA Of SPORTS Club COACH OF PENCAK SILAT IN ELEMENTARY SCHOOL STUDENTS

\begin{tabular}{|c|l|l|}
\hline No & \multicolumn{1}{|c|}{ Competency } & \multicolumn{1}{c|}{ Uraian } \\
\hline 1 & $\begin{array}{l}\text { Education } \\
\text { qualification }\end{array}$ & $\begin{array}{l}\text { Primarily from bachelor of sports coaching } \\
\text { education }\end{array}$ \\
\hline 2 & $\begin{array}{l}\text { Certificate/ } \\
\text { license }\end{array}$ & Minimally basic level \\
\hline 3 & $\begin{array}{l}\text { Ex-athlete and } \\
\text { champions }\end{array}$ & Local, national, or interrnational champion \\
\hline 4 & $\begin{array}{l}\text { Coaching } \\
\text { experience }\end{array}$ & $\begin{array}{l}\text { Primarily the coach that has done coaching } \\
\text { before, minimally local club }\end{array}$ \\
\hline 5 & Characters & $\begin{array}{l}\text { Has leadership spirit, patient, } \\
\text { communication } \\
\text { responsills, } \\
\text { sportivity }\end{array}$ \\
\hline 6 & Leadership \\
\hline 7 & Communitine, \\
\hline 8 & Soft Skill & Humble, concern, and humomote \\
\hline 9 & Power & $\begin{array}{l}\text { Professional in elatih yang ahli dibidangnya, } \\
\text { has license }\end{array}$ \\
\hline 10 & Multirole & $\begin{array}{l}\text { As the coach, teacher, parent, and friend } \\
\text { Open minded and good language expression }\end{array}$ \\
\hline
\end{tabular}

The design stages carried out by the elementary school pencak silat sports club conducted by the trainer are:

a. Development of a training program that consists of an annual program, macro, micro to training unit.

b. Periodic presentation of the training program.

c. Test, measure, evaluate, and follow up on the results to improve the training program.

d. Periodic report presentation increases performance.

e. Promoting athletes who excel.

f. Recommend degradation in athletes who do not perform.

g. Resign if talented athletes do not increase his achievement. hierarchy

The diagram below, represents the coaching

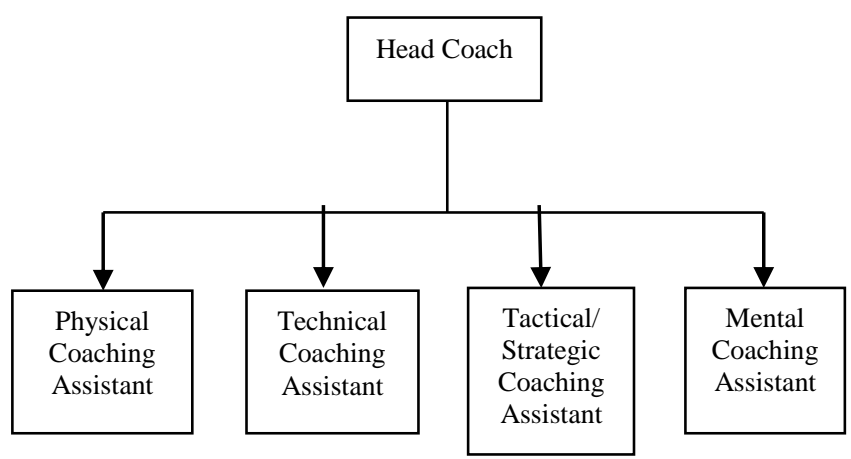

Fig. 2. Coaching staffs

\section{DISCUSSION}

Success depends on how the sports coaching system in an area is implemented. The sports coaching system should focus on two categories, namely; (1) physical education and national sports organizations in school programs, recreation, and sports clubs as well as the national sports organization structure, and (2) the system of applied sports training. Coaching sports to achieve success in martial arts sports club for elementary school students in Bali province.. The training system for achieving martial arts teachers in elementary schools in Bali needs to be supported by professional sportsmen, stakeholders and properly utilized using sport science and technology. In martial arts the techniques are not all utilized in accordance with the application process and the categories contested. The categories to compete include matches, singles, doubles, and teams.

The success of the design of elementary school martial arts sports clubs can be seen from the quality of graduates, governance and management, facilities and infrastructure. Furthermore, it can be seen in the role of school committees, achievement, awards given to trainers, teachers, and students, as well as the level of welfare, activity and creativity of students, School martial arts sports clubs can be established in the provincial districts of Bali with regard to; (1) the physical condition of the school, the availability of infrastructures, facilities, students, trainers, teachers, principals, school committees. (2) Teachers and trainers with high IQs, dedicated and committed to performing their duties in schools using Integrated Quality Management (MMT), (5) commitment of all parties starting from central government, regional government, school committees, principals and staff, guardians, community, students, and (6) the optimization of the role of school committees.

In an effort to improve sports and academic achievements with the design of elementary school students, martial arts sports clubs should be implemented. This sporting activity should be from planning to program implementation, to programmatic evaluation. The design of elementary school martial arts sports club should be evaluated periodically and continuously. Evaluation and the design program of elementary school kids martial arts club can be carried out in the following ways; student recruitment system, curriculum modification, professional trainers, teachers, learning infrastructure and sports facilities, instructional media, supporting facilities, nutritional intake, management, health condition, training system and sport achievement result. Achievement associated with sporting achievements, and programmed output, is simultaneously the result of a longterm, gradual, tiered, and systematic coaching process of talented athletes. Development and fostering of gold age athletes, need comprehensive management. The establishment of an elementary school martial arts sports club needs to be done in-line with the sports club's policies, goals, objectives and needs. The main objective of establishing sports clubs in elementary schools is to produce superior seeds and increase sport performance optimally.

Based on the results obtained from mapping sport achievements in the PORJAR 2014-2016 games, the City of Denpasar and Badung regency bagged the award of very good coaching cities. Similarly, the Gianyar, Buleleng Regency District, and the District of Bangli, need to improve and develop their performance in sports. The results of the 
interviews conducted on leaders of sports field of youth education and sports district / city in Bali province with regards to martial arts club students were based on the ideas and policies of leaders, and not based on scientific studies which involved sports experts. From the results of sport achievements obtained in PORJAR 2014-2016, it can be seen that the city of Denpasar and Badung regency still dominated in the achievement of students / athletes is , while the districts of Klungkung, Karangasem, Tabanan and Jembrana, still lacked willpower. Based on the performance recorded, it necessary to provide training facilities through the design, and implementation of martial arts club at the elementary level.

The existence of sports coaching for martial arts students in Bali province is basically to increase sports achievements efficiently and effectively through formally and centrally organized training. Tremendous continuous achievement is a combination of athlete effort and trainers hard work (Djoko Pekik Irianto, 2009). The sports development of students in Bali province is influenced by technique used in training these athletes in various stages, which is supported by various facilities, at the regional, national, and international level.

Athletic sports coaching at the martial arts club in Bali province refers to the pattern used in carrying out local and national sports coaching, which includes the involvement of the sports coaches. The training system of students' sporting achievement in the tiered and sustainable Bali provinces needs to be supported by professional sporting stakeholders and utilized by the sport science and technology.

Techniques used in the development of golden age athletes, should be able to meet the academic aspects and sports skills at both the international and national level. The coaching system comprises of three system, namely: (1) student admissions system, (2) academic development and sports skills process, and (3) evaluation process (Setiono, 2006). To improve the performance of all system, there must be an improvement on the recruitment system of elementary school students by attracting talented athlete candidates who have potential, sporting achievement, and academic.

The sports coaching system begins with a talented sporting student process. This is also known as the "athlete hunting achievement". The standard of martial arts skills students possess is the most essential part of the coaching process. In addition, another important part is the process of measuring students' physical abilities.

The martial arts teacher should be at least a bachelor's degree holder in sport coaching education, sports education or sports science. This will enable the trainer to understand the factors and the stages of student development to prevent difficulty in approaching the students. The trainer should also be able to make appropriate training plans, and carry out the training in accordance with the plans that have been made using the science and technology approach.

Trainers have many roles and responsibilities that directly or indirectly affect the performance and development of developed athletes. In addition to preparing athletes to compete, the coach must also be able to evaluate the athlete and himself. With reference to the development of the sporting world today, only the trainers who master the sport science and technology can bring the athlete achieve with the expected achievement. Sports science is not standalone industry, but rather an industry related to other disciplines. Undoubtedly, knowledge of the fundamentals of coaching supported by sports technology will greatly strengthen the roles and responsibilities of the coach.

A professional coach is one with authority, the right educational qualifications, and competence. This will enable the head coach who is assisted by the physical assistant trainer, assistant technical trainer, assistant or strategy coach, and mental assistant coach to improve their coaching pattern. Qualifications and abilities should also be improved. Some of the minimal skills that the trainer must master are; appreciation of professional ethics, the understanding and application of sports science, the mastery of skills in a sport, the mastery of teaching and learning strategies or training, social skills include the ability to socialize, communicate, lead, make humor, influence others, and mastery of training programs.

\section{CONCLUSIONS}

The design of elementary school martial arts sports club is arranged based on PORJAR. This program is regularly carried out once a year as an evaluation technique used to evaluate sports coaching at the district level of Bali province. The design of sports clubs and martial arts in elementary school is expected to raise and enhance contributions to regional and national sporting achievements. The conclusions obtained in the study are as follows: (1) Recommendation of needs analysis of youth education and sports district / city in the province of Bali to the concept of sports club pencak silat students, (3) design of martial arts club students, in each regency / municipality of Bali province based on the potential and ability of the region, and (3) Proper management of the formation of martial arts club based on scientific studies.

\section{REFERENCE}

[1] Asdep Sentra Keolahragaan. Petunjuk Pelaksanaan Pusat Pendidikan dan Latihan SMP/SMA Negeri Ragunan. Jakarta: Kemenpora, 2012)

[2] Pedoman Pengelolaan dan Petunjuk Pelaksanaan Pusat Pendidikan dan Latihan SMP/SMA Negeri Ragunan Jakarta: Kemenpora, 2012

[3] Bompa, T.O. Theory and Methodology of Training. Dubuque: Kendal Hunt Company, 1990.

[4] Bompa Tudor O and Haff Gregory G. Periodization: Theory and Methodology of Training. United States: Human Kinetics, 2009.

[5] Grosser, et.al. Latihan Fisik Olahraga (Conditionstraining). Diterjemahkan oleh Paulus L.P. Satuan Pelaksana Prima Pratama. Jakarta: Prima Pratama 2012

[6] Harsono. Coaching dan Aspek-aspek Psikologi dalam Coaching. Jakarta: P2LPTK Ditjen Dikti Depdikbud,1998.

[7] Lubis Johansyah dan Evalina Heryanty. Latihan Dalam Olahraga Profesional. Jakarta: Badan Pengembangan dan Pengawasan Olahraga Profesional Indonesia, 2007

[8] Lumintuarso Ria. "Pembinaan Multilateral Dalam Pendidikan Jasmani dan Olahraga Prestasi.” Disertasi, Universitas Negeri Jakarta, 2011.

[9] Mcmorris Terry dan Hale Tudor. Coaching Science: Theory Into Practice. England: John Wiley \& Sons Ltd, 2006. 
[10] Setiono Hari. Model Sistemik Pembinaan Atlet Berprestasi. Jurnal IPTEK Olahraga, Volume, 8, No. 1, 2006.

[11] Sri Sudono Sumarto, 2000. Klub Sebagai Ujung Tombak Pembinaan Olahraga di Indonesia. Malang: Seminar Ilmiah Keolahragaan PON $\mathrm{XV}$

[12] Sudiana Ketut dan Sepyanawati Putu Ni Luh.2017. Keterampilan Dasar Pencak Silat. Jakarta Penerbit RajaGrafindo Persada. 2017

[13] Suratmin, I Made Budiawan, dan I Wayan Artanayasa. Pola Pembinaan Cabang Olahraga Pelajar Kota Denpasar dan Buleleng dalam Upaya Membangun Prestasi Olahraga Bali, Singaraja: Undiksha, 2009.

[14] Suratmin, Gede Eka Budi Darmawan, Darmayasa Putu. Maping The Sport Club Students in Bali. Jurnal Active Unnes. 2017

[15] Suratmin, Adnyana Putra, dan Darmayasa Putu. Pengembangan Desain Model Klub Olahraga Pelajar Provinsi Bali. Singaraja: Undiksha, 2017

[16] Design of Measurable Sports Club in Elementary School in Bali Province. Yogyakarta: International Conference, 2017

[17] Tangkudung James. Kepelatihan Olahraga Pembinaan Prestasi Olahraga. Jakarta: Penerbit Cerdas Jaya, 2006.

[18] Undang-Undang Nomor 3 Tahun tentang Sistem Keolahragaan Nasional Tahun 2005

[19] Wahjoedi, dkk. Olahraga Unggulan di Provinsi Bali. Jakarta: Kemenpora, 2009. 